\title{
The Local Genius Values of Minangkabau Society
}

\author{
Misnal Munir \\ Faculty of Philosophy \\ Universitas Gadjah Mada \\ Yogyakarta, Indonesia, \\ misnalmunir@ugm.ac.id
}

\author{
Moses Glorino Rumambo Pandin \\ Faculty of Philosophy \\ Universitas Gadjah Mada \\ Yogyakarta, Indonesia \\ moses.glorino.r.p@mail.ugm.ac.id
}

\begin{abstract}
The aim of this study is to describe the principles local genius values in Minangkabau culture and society. Based on Bahm and Frondizi theories of values and make used of qualitative method, especially hermeneutic, the research generated findings such a) the source Minangkabau values is the Al-Qur'an, b) the Minangkabau community places the mind as the determinant of value based on to the value of goodness, and evil, c) the values of life are a reflection of personal values and cultural values that are connected cooperatively, interpretive, and dynamic. Goodness is more about mood (moral) and beautiful is about language (speech), the correlation of subjective and objective values more intrinsic values as objective, since custom is considered an objective value system that can affect human behavior, d) the actual and potential value is opened to the development of society and sciences. It was said to be potential because it has the power to be obeyed by Minangkabau residents in particular, e) in general the values of appearance and real value in Minangkabau society are reflected in the custom which contains four things, namely raso, pareso malu, sopan, these values as principles values for a man to be called real human or person.
\end{abstract}

Keywords_- local genius; Minangkabau; values

\section{INTRODUCTION}

The role of values in human life is irrefutable, meaning both individually and socially, humans need value for the sustainability of their existence. Frondizi even asserts that the fundamental issue of axiology is not only emerging in the scientific world, but also in the everyday world. [1, p. 16]. When there is a difference of opinion about something (e.g., an assessment of the delicious kind of cuisine by 3 culinary connoisseurs), then that's when a fundamental problem of axiology arises. Here goes the Latin proverb that reads: de gustibus non disputandum (taste not arguable). It is always possible to have an opinion on values that differ from one another, even though they all agree that the issue of value is just as important.

The human interest of value is beneficial to man. There are several benefits of human value that can be detailed as follows: first, value can help people to find the most essential meaning of life that is for what humans live in this world. Second, value can help human beings find standardization. Because the differences that arise in the issue of value is very possible for conflict between individuals or between groups. Third, values can make people commit and responsible for their speech and actions. Fourth, value can help people to answer the problems of life that develop along with the development of the era. Fifth, value can help a community to develop and develop customs that are useful for the way of life of the community. These value benefits will be explored further in this study.

The Minangkabau society named their homeland as Minangkabau Nature (alam Minangkabau), because the use of the word of "nature" contains meaning which is incomparable. Nature for them is everything, not only as a place of birth and death, a place of life and development, but also a philosophical meaning. This is expressed in the proverb that says: "Alam takambang jadi guru (expended Nature becomes a teacher)". Therefore, these Minangkabau teachings and worldviews are cited in the proverb, petitih, and adverb, mamangan that take the expression of form, nature, and natural life [2, p. 59]. Thus, the axiological principles in Minangkabau culture are an important part of community development based on local wisdom. follow.

\section{MinangKabau Culture VAlues}

The study of the theory of values is axiology (Gr. Axios, of like value and logos, theory). Pure axiology is the study of the values of all types. [3, p. 22]. Frondizi [1, p. 7] asserted that the value is a quality that is not real, because the value is not there for himself, he needs developers to be.

The term values contain complex and varied uses. According to Lacey there are at least six notions of value in general usage: (1) Something fundamentally sought by people throughout their lives, (2) A quality or a valuable action, goodness, meaning or fulfillment of character for one's life, (3) or a partial act of forming one's identity as self-evaluation, self-interpretation, and self-formation, (4) A fundamental criterion for one to choose what is good among the various possible actions, (5) A fundamental standard held by a person when behaving for himself and others, and (6) a "value object", a precise relation to something that simultaneously forms a precious life with the identity of one's personality. Value objects include works of art, scientific theory, technology, sanctified objects, culture, traditions, institutions, others, and nature itself [4, p. 23].

One example of value objects related to culture is about Minangkabau society. Minangkabau is often better known as a form of culture than any form of state or kingdom that ever existed in history [2, p. 1]. The Minangkabau Principles of Culture can be found in "Tambo" which is hereditary inherited by verbal. Tambo is a work of historical literature, a literary work that tells the history (origin) of the tribe, the origin of the country and its customs, namely Minangkabau. This literary work of history can also be called traditional historiography, the writing of a country's history based on the hereditary beliefs of society [5, p. 1] 
The Minangkabau culture is the rule of community life in Minangkabau created by his ancestors, namely Datuak Perpatieh Nan Sabatang and Datuk Katumanggungan. His teachings distinguish sharply between humans and animals in behavior and deeds, which are based on the virtuous teachings of good and morally noble fellow human beings and in their environment. It means that the custom governs the life of the community, both individually and collectively in every behavior and deed in association, which is based on good and noble manners, so that each person is able to feel in himself what is felt by others [6, p. 13].

The Minangkabau community is known as a community group that imitates the harmony of natural law system. That is, they can be likened to all elements of nature different levels and roles. The elements are interconnected, but not binding, clashing each other, but not eliminating each other, and clustering together but not melting each other [2, p. 59]. Syafii Ma'arif [7, p. 129] adds that humans according to the Minangkabau adage must have the same status and position before history, despite having different functions, such as the different functions of the sun and earth, water and air.

In the Minangkabau nature philosophical views have functions and roles that suit their ability and duties respectively. The Minangkabau culture proverb reinforces this attitude of life with the phrase "the blind blower of the mortar, the deaf rickshaws, the crippled inhabitants of the house, the mighty bearers of the load, the foolish to be ordered, and the clever opponents confer" [8, p. 67]. In addition Minangkabau community is also known as a very open society in accepting change. The tribe of the Minangkabau nation is well known for its pioneering work in pushing the minds of modern thought without abandoning the cultural values that have been entrenched in their culture. [9, p. 98].

Another uniqueness of the Minangkabau community is the high appreciation of women as it is cited and revealed in the research of Peggey Reeves Sanday [10, p. 82]. The search for axiological values in Minangkabau culture requires a theoretical framework of value. In this case researchers used the theory of values Archie Bahm [11] and Frondizi [1], which it describes the various types of values in human life with a scheme of six pairs of values, namely good and bad, ends and means, subjective and objective values, apparent and real values, actual and potential values, pure and mixed values.

Bahm, an expert on value issues, suggests that the notion of the nature of values is very complicated, as it involves the fact that many different types of values exist and that more chaos about value is caused by wrong ideas. Therefore, to avoid misunderstanding about this value problem, the researcher will trace comprehension of value comprehensively, not by giving definition, but rather emphasize on illustration and description [11, pp. 51-173].

The value according to Frondizi's thought is the quality of the value-bearer as it is: the beauty of a painting. There are three categories of quality, namely primary, secondary, and tertiary qualities. Primary quality is the basic quality without which the object cannot exist, Secondary quality is a quality that can be captured senses, Tertiary quality is a quality that is not real, not independent, is parasitic, and is polar and hierarchical. Value is said to be independent, meaning that value is not free, because it must be attached to something.

\section{RESEARCH METHOD}

This research are literature research and field observation, especially in culture proverb related to axiological principles of Minangkabau culture. To strengthen the data, the researcher did interviews were conducted with Minangkabau culture leaders in West Sumatra and community leaders in Yogyakarta.

The research is conducted through two steps: first step with the Collection, Classification, Analysis, and Interpretation of axiological principles in Minangkabau culture. The second step with the hermeneutic-philosophical method, the researcher describes the axiological principles in Minangkabau culture based on the literature and interviews, interpreting the petitih proverb contained in the Minangkabau culture by reading the text and testing it with field data, so there is a hermeneutic circle between text-based data and reality in the field.

The research is using inclusive language, the understanding of the Minangkabau pepatah-petitih and tambo culture originally derived from the Minangkabau language was adopted and understood in a broader sense, and idealized, to find an axiological principle that could be used as an alternative to understanding science and developing knowledge.

\section{Result and Discussion: The Value Principles of MiNANGKABAU SOCIETY}

\section{A. Good and Bad Values:}

For Minangkabau people, good and bad values are two things that always exist in human life. This means that someone who does good will generate respect for others, but on the contrary someone who does evil will cause disrespect, protest, aggravation, even anger of others.

- The good value in Minangkabau society is expressed in poem Nan kurik iyolah kundi, nan merah iyolah sago, the good is the mind (moral), the beautiful is the language (speech). Dignity in Minangkabau culture, especially for a culture leader (penghulu) is to maintain prestige in leading the community. Someone who has been appointed as penghulu, be an example and role model for the community he leads. Idrus Hakimy Dato Rajo Penghulu [6, p. 62-67] argues that if a penghulu wants to be dignified and respected then he must understand and have the following things: Remember jo jago on custom, (Remember and keep culture), a penghulu is culture officers always keep their good name as culture customary leader, while badness value for society is expressed.

- Tahu dek bantanyo, pandai dek baguru (Knowing for asking, clever for learning), a penghulu must have extensive knowledge to become a leader. With extensive knowledge a penghulu leads his society wisely and away from error, or error, the proverb describes the nature of 
the penghulu. Thus a culture leader must be careful in speaking and acting.

- Kayo pado hati dan kabanaran, (rich in heart and truth). Kayo to the heart and truth, meaning a penghulu is humble, kindness, patient, broad-minded, and logic (not emotional), and always honest and sincere towards the community.

- Maha dan murah pado laku dan parangai yang bapatutan. This means that a penghulu in everyday social, behavior and his temperament see the atmosphere, there are expensive time and there is cheap time, put something in its place, see situation and condition, place and situation.

- Hemat jo cermat. Mangana awa jo akhia, it means that a penghulu must always be careful in action, is thinking about the cause and effect of an action.

- Saba jo rila, fasih lidah bakato-kato, it means a penghulu is patient and clever for choosing the right words that he pronounced.

\section{B. Ends and Means}

The difference between means and goals is crucial to understanding the nature of values. This distinction is meant to prevent chaos and misunderstandings of value problems. Means and goals are two interdependent things, because the means are the means of the goal, while the end is the end of the means. According to Bahm, the technical language of the means refers to the instrumental value, while the technical term of the objective refers to the intrinsic value. So something is said to be instrumental value because it serves as the cause. [11, pp. 5455].

- Principle of Life: the purpose of life for the Minangkabau people is to do merit. The Minangkabau word heirloom says that "hiduik bajaso, mati bapusako" [12, pp. 19-22]. The Minangkabau people give meaning and high price to life. Analogizing to nature, with the comprehension that the Minangkabau people live is not like living animals that do not think of the next generation, with everything to be left behind after death. The culture phrase also says "Pulai batingkek naik maninggakan ruas dan buku, humankind is leaving the good name and heirloom. With the wealth, everything can be done, so as not to bring shame for himself or his family. The number of ceremonial customs such as marriage and others require financial supports. The value of the Minangkabau community's goal is to live meritoriously for others and leave a good name for the next generation.

- Principle of Work: In line with the meaning of life for the Minangkabau people, which is meritorious to their relatives and society, work is a highly valued activity. Work is a must. Work that can make people able to leave the heirloom for the child's nephew. With the richness of everything can be done so as not to bring shame for himself or his family. The number of ceremonial customs such as marriage requires a fee. From that the earnest effort and hard work is very important.
Minangkabau people are told to work hard, as also expressed by the customary fatwa. The hard work ethic that is already a basic value for the Minangkabau is enhanced by the Islamic view that says people have to work hard as if he lives forever, he has to continue doing as if he will die tomorrow.

- Principle of Time: for the Minangkabau the precious time is the view of the Minangkabau's life. Minangkabau people have to think about his future and what he will leave after death. They are advised to always use time for meaningful purposes, as it says "Duduak marauik ranjau, tagak maninjau jarak". The dimensions of time, the past, the present, and the future are the time spaces that should be of concern to the Minangkabau.

- The Principle on Nature: The beautiful and mountainous nature of Minangkabau, the sea, the sea and the lake, rich with flora and fauna has inspired the people. Mamangan, pepatah, petitih, and culture expression cannot be separated from nature. Nature has an important position and influence in Minangkabau culture, it turns out from the customary teaching itself which states that nature should be made teacher. Therefore Minangkabau culture philosophy is based on the provisions in nature, then the Minangkabau custom will remain as long as this nature exists.

- The principle to Others: In social life, the Minangkabau uphold the value of egalitarianism or togetherness. This value expresses them with the phrase "Duduak samo randah, tagak samo tinggi". In activities related to the public interest their communal and collective nature is very prominent. They highly uphold deliberation and consensus. The use of common sense is required by Minangkabau people and highly valued human beings who use reason. The values brought by Islam put the Muslim mind first, and Islam complements the use of reason with the guidance of faith.

According to the custom the view of one's self towards the other should be the same even though one has different functions and roles. Although different are needed and need each other so there is togetherness. The arrival of Islam reinforces the concept of Minangkabau about the views of others.

The egalitarian value which the Minangkabau upholds encourages them to have high self-esteem. Collective values based on matrilineal social structures that emphasize widespread responsibility such as from the people to the nagari community, cause a person to feel ashamed if they do not succeed in contributing something to their relatives and nagari society. This interaction between self-esteem and social demands has caused the Minangkabau people to always be dynamic.

The ideal qualities of the Minangkabau are:

- Hiduik baraka, baukua bajangko, (long life intellectual measured) meaning the life of the Minangkabau people must have a meaning clear and precise estimates. 
- Baso-basi jo sopan, traditional Minangkabau prefer socially polite in neighborhood.

- Tenggang raso, in good social circles taught always be careful when talking and not offensive other people.

- Faithful, Minangkabau people should be united in the life of others, whether during difficult or happy

Similarly, the relationship of men and women in society, shows that men and women have a separate role in society. For Minangkabau women and men to understand the role and position of each of course will give spirit and encouragement to carry out duties and obligations as Minangkabau people.

\section{A. Subjective \& Objective Value:}

Minangkabau people are famous for their customs. Culture is very important in the life of the people. Therefore in the Minangkabau proverb expressed, hiduik dikanduang adat. Culture in Minangkabau society is the value that becomes the life guide. Culture is said to contain intrinsic value means that the position of culture is very elevated and essential for the life of the Minangkabau community. There are four levels of culture in Minangkabau.

- Adat Nan Sabana Adat: culture nan sabana culture is a fact that holds true in nature, never changed by the state of place and time. That fact contains values, norms, and laws. In essence, this custom is a custom which occurs with the will of God. It serves as the main basis of Minangkabau norms, laws, and rules. Culture in this first sense is an intrinsic value, a fixed value.

- Adat Nan diadatkan: is culture custom made that is planned, designed, and compiled by the ancestors of Minangkabau people to be applied in everyday life. The Minangkabau people believe the two figures as designers, planners, and compilers adat nan diadatkan, are namely Datuak Parpatiah Nan Sabatang and Datuak Katumangguangan. At first glance, the two concepts of culture are opposite. But in practice both concepts meet, mingle, and complement each other. Combined both gave birth to a distinct democracy in Minangkabau.

- Adat Nan Taradat: is a customary provision arranged in the nagari to carry out adat nan sabana adat and culture nan compressed in accordance with the circumstances and needs. This custom is composed by the leaders and nagari community leaders through deliberation and consensus.

- Adat Istiadat (Customs): Customs are custom rules that are made by consensus ninamak mamak in a nagari. This regulation accommodates all the will of the appropriate nagari child according to alua jo patuik, patuik jo mungkin. Aspirations channeled into customs are aspirations that match the custom jo limbago, manuruik barih jo balabeh, manuruik ukuran cupak jo gantang, manejik alua jo patuik.

\section{B. Appearance and Real Values:}

The values contained in Minangkabau culture teachings according to the Indigenous language are: Raso, Pareso, Malu Sopan (four) kinds. The loss of these four kinds in a person is called a person who does not know at AMPEK. Like from someone already gone "raso jo Pareso, malu jo sopan". Such a person is a human-shaped animal (as with animals) because his behavior has resembled the behavior of animals in the intercommunal relationship. Raso: is what feels on self. Pareso: is the nan the insured for the heart. Embarrassed: it is a liability. Polite: is the behavior of someone who is built by raso, pareso, dan malu. The loss of the four kinds is gone all the way. The four kinds mentioned above are manifestations of good manners from someone. So the values of culture teachings are good manners and have a sense of shame in themselves. Both of these are the teachings that coincide with the teachings of Islam and for that Prophet Muhammad SAW into the world he said: "Indeed I am sent to improve man's human nature. Perfection The faith of a believer lies in his good spirit. Shame is part of the Faith. If you will not use the shame, make it your will (Al-Hadist). The saying goes: "Nan kuriak kundi, merah nan sago, nan baiak budi, nan indah bahaso".

Good and noble manners are all things according to Minangkabau custom which is a fine smooth rope that connects human with good man. Losing a good manners to a person, society and nation, will invite destruction in the society. Shame is the commendable nature that every adult and intelligent male and female must possess. The loss of shame for a human being loses his self-worth as well as his dignity as a human being, falling into the same animal's dignity.

Objectives to be achieved by knowing and implementing the objectives to be achieved by practicing Culture well and correctly mentioned in the Minangkabau Culture provisions. This means that the goal to be achieved according to Minangkabau custom begins first by creating "Bumi sanang", order in small or large communities such as family, community and nation. With the creation of order in all spheres the realization of tranquility and security, which in turn will lead to stability in all fields, allowing for development, morale, mentally - spiritual.

\section{Actual \& Potential Value;}

Culture also teaches how a person should have praiseworthy characteristics in the life of society. The properties are as follows:

- The principle of mutual love and mutual-respect, as it is said by the custom so that fellow human beings should sasakit sasanang, sahino samalu, sabarek saringan.

- The principle of tolerance, in association should keep the feelings of others (tolerable tolerance), it can be concluded that our attitude in society should be mutual respect and mutual tolerance or said also "lamak dikawak, katuju dek urang"

- The Principle of shame, a person should have a sense of shame, especially between men and women, this is to keep away from going free sex.

- The principle of doing good, always doing good deeds of fellow human beings, such as mutual cooperation, help, advice advise, remember-remind, uphold sense of togetherness. 
- The principle of humble, one is required by custom to abstain from being arrogant, indifferent to others.

- The principle of courageous, courage must be on someone, dare because true fear because wrong.

- Attitudes to help, in the social life of the principle of help must exist in a person, because we ourselves as human beings do not escape the help of others.

The customs of manners are a reflection of the customary experience with good character, using raso, pareso, malu and sopan in every behavior and association. Culture Minangkabau requires that all the outward nature must reflect the nature of culture teaching which leads to the mind, as it is said in the culture adage "nan kuriak iyolah kundi, nan merah iyolah sago, nan baiak iyolah budi, indah iyolah baso".

Basically Minangkabau culture is a value order that becomes the benchmark for Minangkabau people in living everyday life for Minangkabau society. The Minangkabau culture value order based on syara', the basis of syara' value becomes the guideline for sustainability and a foothold for Minangkabau customary sanction. Although the Minangkabau custom is man-made, the creation of the Minangkabau ancestors, but clearly there are still relevant custom values.

The proverb says that "usang-usang dipabarui. Adat nan elok samo dipakai, nan buruak dibuang jo etongan”, it can be understood that Minangkabau culture is accessible to the development of society. The Minangkabau culture gives way for a possible reshuffle if the custom is less appropriate with the development of the era.

\section{CONCLUSION}

First, the value system in Minangkabau society is loaded with axiological principles. The source of value in Minangkabau culture is the Koran, it is found in various Minangkabau culture customs, culture basandi syarak, syarak basandi kitabullah (alQuran) (adat bersendi syariat, syariat bersendi kitabullah); Second, the value in the life of the Minangkabau community is a reflection of personal values and cultural values that are connected cooperative, interpretive, and fluctuating. It is said to be cooperative because a Minangkabau citizen can only cooperate with Minangkabau community if he adheres to the cultural values contained in culture. Interpretative because he can apply the Minangkabau culture even though he is abroad, in this case apply the principle where the earth is rested there sky is upheld. Fluctuate means the value of Minangkabau culture can experience development or silting through the power of raso pareso that applied to each individual in the life of society; third, good value for Minangkabau society is reflected in the expression Nan kurik iyolah kundi, red nan iyolah sago, good is mood (moral), beautiful is language (speech). The value of evil means when one cannot nurture the words and words in the association; fourth, the correlation of subjective and objective values in the Minangkabau society places more intrinsic value as objective, since custom is considered an objective value system that can affect human behavior; fifth, the actual and potential value of Minangkabau society is contained in the expression of obsolete updated. The Minangkabau culture is actual, because open to the development of society and era. It is said to be potential because it has the power to be obeyed by Minangkabau residents in particular, the general public at large; sixth, the value of appearance and real value in Minangkabau society is reflected in the custom which contains four things, namely raso, pareso, malu, sopan. If a person loses these four values, then he is called a person who does not know raso jo pareso, malu jo sopan", he no longer recognize as human being.

\section{REFERENCES}

[1] R. Frondizi, What is Value? (C. A. Wijaya, Transl.), Yogyakarta: Pustaka Pelajar, 2001

[2] A. A. Navis, Alam Terkembang Jadi Guru; Culture dan Kabudayaan Minangkabau [Nature Develops and Becomes Teacher: Culture of Minangkabau], Jakarta: Grafiti Pers, 1986.

[3] M. D. Hunnex, Chronological and Thematic Charts of Philosophies and Philosophers. Michigan: Chandler Publishing Company, 1986.

[4] H. Lacey, Is Science Value Free? London: Routledge, 1999.

[5] E. Djamaris, Tambo Minangkabau: Suntingan teks disertai Analaisis Struktur [Tambo Minangkabau: Text editing with Structural Analysis]. Jakarta: Balai Pustaka, 1991.

[6] I. H. Dt. Rajo Penghulu, Pokok-Pokok Pengetahuan Culture Alam Minangkabau [Knowledge Principals of Minangkabau Realm's Culture], Bandung: Remaja RosdaKarya, 1994.

[7] A. S. Ma’arif, “Gagasan Demokrasi dalam Perspektif Budaya Minnagkabau [Idea of Democracy in Minangkabau Cultural Perspective]", in Demokrasi dalam Perspektif Budaya Nusantara [Democracy in Perspective of Nusantara's Culture], M. Najib, et al., Eds. Yogyakarta: LKPSM, 1996.

[8] M. Nasroen, Dasar Falsafat Culture Minangkabau [Basic Phylosophy of Minangkabau Culture], Jakarta: Penerbit Pasaman, 1957.

[9] N. Hars, Profil Propinsi Sumatera Barat [Profile of West Sumatra Province], Jakarta: Yayasan Bhakti Wawasan Nusantara, 1992.

[10] P. R. Sanday, Women at the Center: Life in a Modern Matriarchy. Corne University, 2002.

[11] A. J. Bahm, Axiology: The Science of Values, Albuquerque, New Mexico, 1984

[12] M. S. Amir, Culture Minangkabau: Pola dan Tujuan Hidup Orang Minang [Culture Minangkabau: Minang People's Patterns and Life Goals], Jakarta: Mutiara Sumber Widya, 2003. 